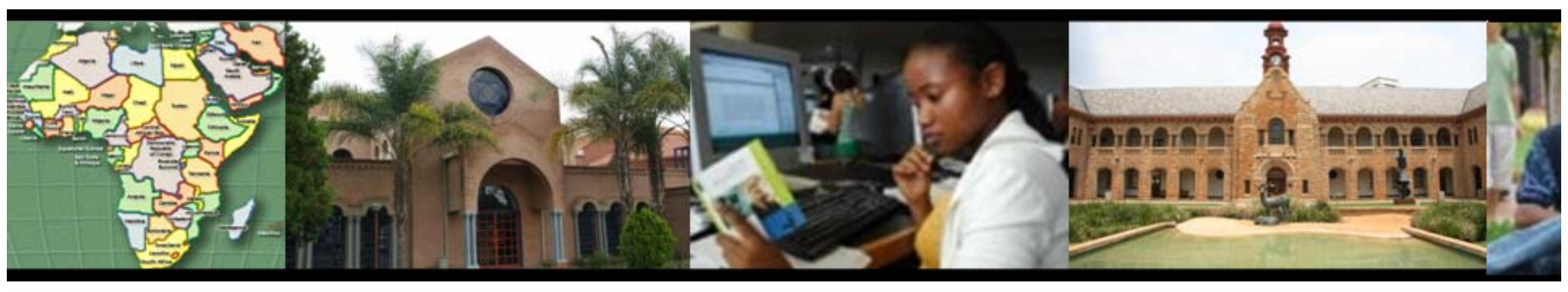

\title{
Development of a Library 2.0 service model for an African library
}

Heila Pienaar \& Ina Smith

$73^{\text {rd }}$ IFLA General Conference \& Council

22 August 2007 


\section{Agenda}

- University of Pretoria context

- Library's e-Information Strategy \& Structure

- Variables that influence the role of academic libraries

- Web 2.0 \& Library 2.0

- Development of a Library 2.0 service model 


\section{University of Pretoria Context}

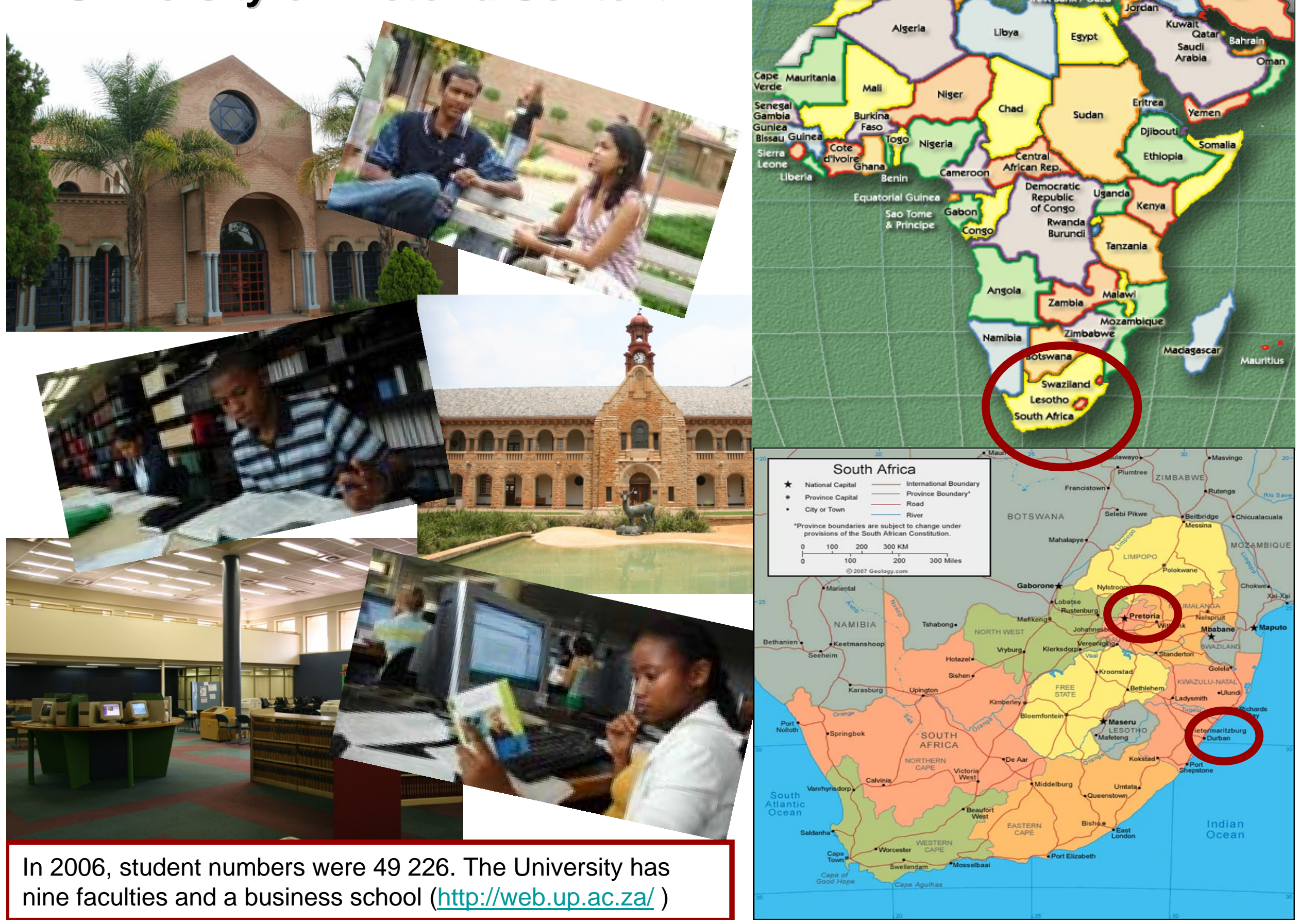




\section{Library's e-Information Strategy}

- Integrated seamless e-Service

- Objectives

- Support education innovation \& research excellence

- Optimal e-information (portal) services

- Participate \& contribute to national \& international e-information phenomena

- Key sub strategies

- Create e-information environment

- E-Information plan

- Learning/ e-learning \& research/ e-research support strategies

- Library structure, business processes, skills, facilities 


\section{Library Structure}

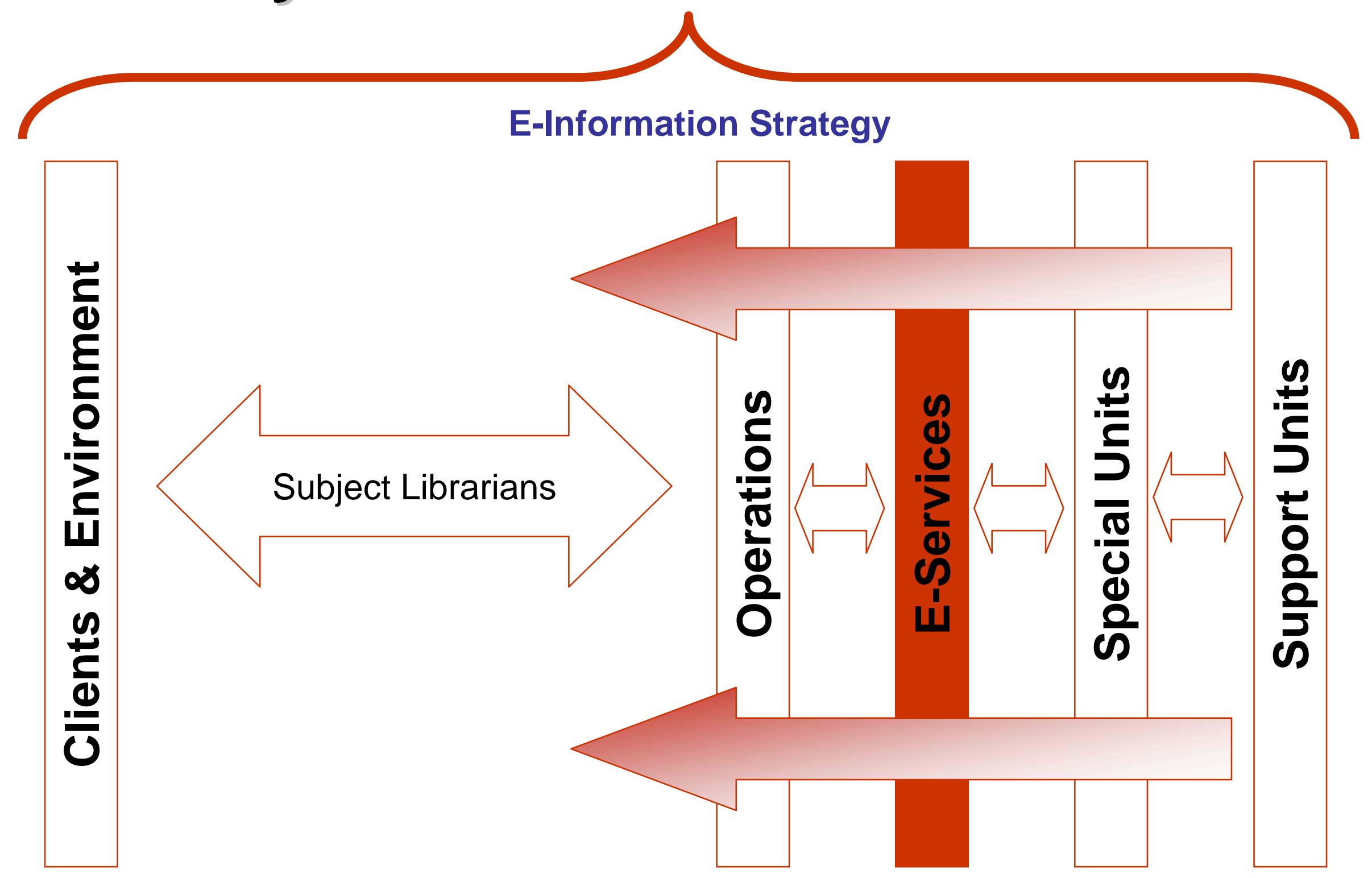




\section{Variables that influence the role of academic libraries}

- Global library digitization projects, e.g. Google, European Union

- Impact of e-Research (a.k.a. e-Science (UK) or Cyber infrastructure (USA))

- Needs of Net-Generation students

- Possibilities created by Web 2.0 / Library 2.0 technologies

- These variables influenced the development of a Library 2.0 service model for the University of Pretoria Library Service 


\section{Web 2.0}

TFITTAGEE:

TFEGLINE 듭IDFLIEIDUE TFGGLDIDD

$$
\text { DDEK DELIEI D }
$$

Wikis

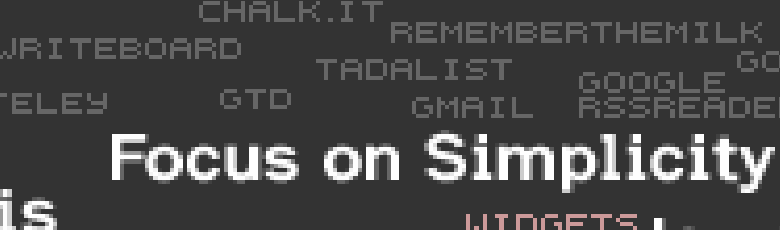

\section{Folksonomy SHFETNS}

WILEETEJoy of Use

Usability

AJAX

The Long Tail
Economy

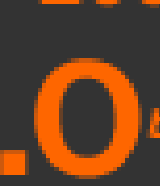

Affiliation
ADSTEEFELITKKEDE
A A FOEICAET ING DFFES MINT

FFIDEFIF Audío

FEFD . I 믐

Video

Convergence

\section{Mobility \\ GAETFEET Mobility WWT} RSS

Remixability EUNDTEAT ION

DFTA INEIDE $\Xi E 0$ GFANULFFA I TU
L I WEL I WESE

Design
OpenAPIs

DataDriven
Standardization IEMANTIE CSS Design Web Standards Microformats 


\section{Web 2.0}

- Web 2.0

- Users build networks (professional, recreational etc.)

- People are the content of sites (O'Reilly)

- Emphasize online sharing and collaboration

- 2.0-style Service Examples

- Google Scholar \& Scholar SFX

- User tagging, ratings \& comments

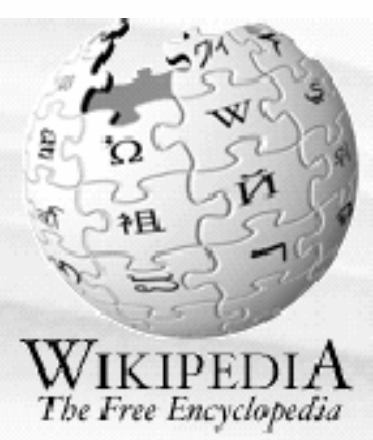

- Mashups, Wikis, Blogs, RSS-feeds

- Community citation (CiteULike), photo and book services

- Websites with 2.0 characteristics: Flickr, eBay, De.licio.us (social bookmarking), MySpace, MyTube, LibraryThing 


\section{Community \& Collaboration on the Web}

"It's a story about community and collaboration on a scale never seen before. It's about the cosmic compendium of knowledge Wikipedia and the millionchannel people's network YouTube and the online metropolis MySpace. It's about the many wresting power from the few and helping one another for nothing and how that will not only change the world, but also change the way the world changes."

Time's Person of the Year 2006: You.

http://www.time.com/time/magazine/article/0,9171,1569514,00.html 


\section{Common traits of 2.0 services}

- Interactivity

- Respects and leverages user contributions

- Complementary/ compatible/ cross-referential

- Treats info as a conversation

- Emphasis on ease of use

- Sharing - use/reuse/remix/mashups encouraged

(Schneider 2007) 


\section{Library 2.0}

"With Library 2.0, library services are frequently evaluated and updated to meet the changing needs of library users.

Library 2.0 also calls for libraries to encourage user participation and feedback in the development and maintaining of library services. The active and empowered library user is a significant component of Library 2.0."

With information and ideas flowing in both directions from the library to the user and from the user to the library - library services have the ability to evolve and improve on a constant and rapid basis. The user is participant, co-creator, builder and consultant whether the product is virtual or physical." http://en.wikipedia.org/wiki/Library 2.0 


\section{Library 1.0 vs Library 2.0}

- Closed collections

- Collection development

- Pre-organized catalogue

- Walk-in services

- "Read-only" catalogue

- Print newsletter mailed

- Easy = Dumb users

- Limited service options

- Focus on bringing them in

- Catalogue is core operation
- Open collections

- Library suggestion box

- User tagging

- Globally available services

- Amazon-style comments

- Team-built blog

- Easy = Smart systems

- Broad range of options

- Focus on finding the user

- User services are core

(Schneider 2007) 


\section{Key Library 2.0 concepts}

- The library is everywhere

- The library has no barriers

- The library invites participation

- The library uses flexible, best-of-breed, componentbased systems

- The library is a human-centered organization

(Schneider 2007) 


\section{Library 2.0 Service Model}

Library

th

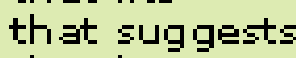

th at le.ヨr rı

that gather 3

that gombiries

that organizes

\section{Lbrary that LET}

The libr ary inuites

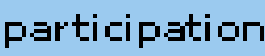

\section{पPA}

- Federited search - RSS for cataloging records 8 segrch results

- Records tagging

- User reuiew

\section{User-centicity}

2. Technology-sarsy enwironment

3. Reaching of the patons long tail

4. Content for more than one device

5. Component-based softw are, not monoli thic ILS

6. Constant change

7. Use of Web 2.0 apps and serrice ?

8. Dpen standards

\section{ST AFF}

Creation of an Emerging Terhnology Committes

Initegr:ation enuir oniment
Librigr is a fr:annew ork for integr:ating ch:пnge into all leuels of libr:ary operations
THE PHYSICAL LIBRARY

Loud spaces for coll abor ation Q conversation

Mobile devices for users

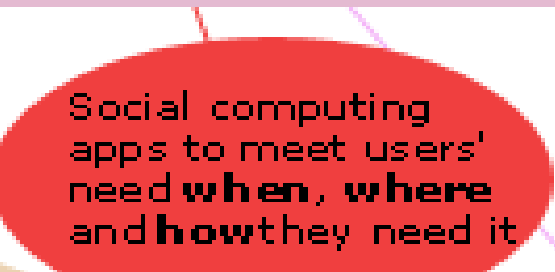

The library uses flexible, best-of-breed systems
The libr ary

has no

b.arriers
The library

is.

human
The library is eueryw here

Patron 2, $0=$ from content consumer to content crejtor 


\section{Enable e-Research}

\section{A New Science / Research Paradigm}

- Thousand years ago:

Experimental Science

- description of natural phenomena

- Last few hundred years:

Theoretical Science

- Newton's Laws, Maxwell's Equations ...

- Last few decades:

Computational Science

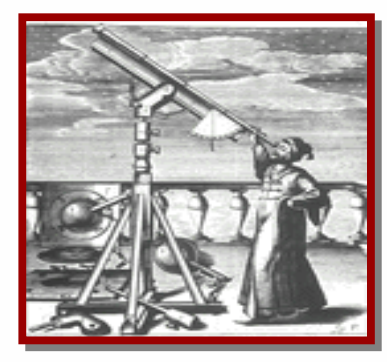

$$
\left(\frac{\dot{a}}{a}\right)^{2}=\frac{4 \pi G \rho}{3}-\mathrm{K} \frac{c^{2}}{a^{2}}
$$

- simulation of complex phenomena

- Today:

e-Science or Data-centric Science

- unify theory, experiment, and simulation

- using data exploration and data mining

- Data captured by instruments

- Data generated by simulations

- Data generated by sensor networks

- Scientist analyzes databases/files 


\section{The e-Science / e-Research Data Life Cycle}

- Data Acquisition

- Data Ingest

- Metadata

- Annotation

- Provenance
- Data Storage

- Data Cleansing

- Data Mining

- Curation

- Preservation 


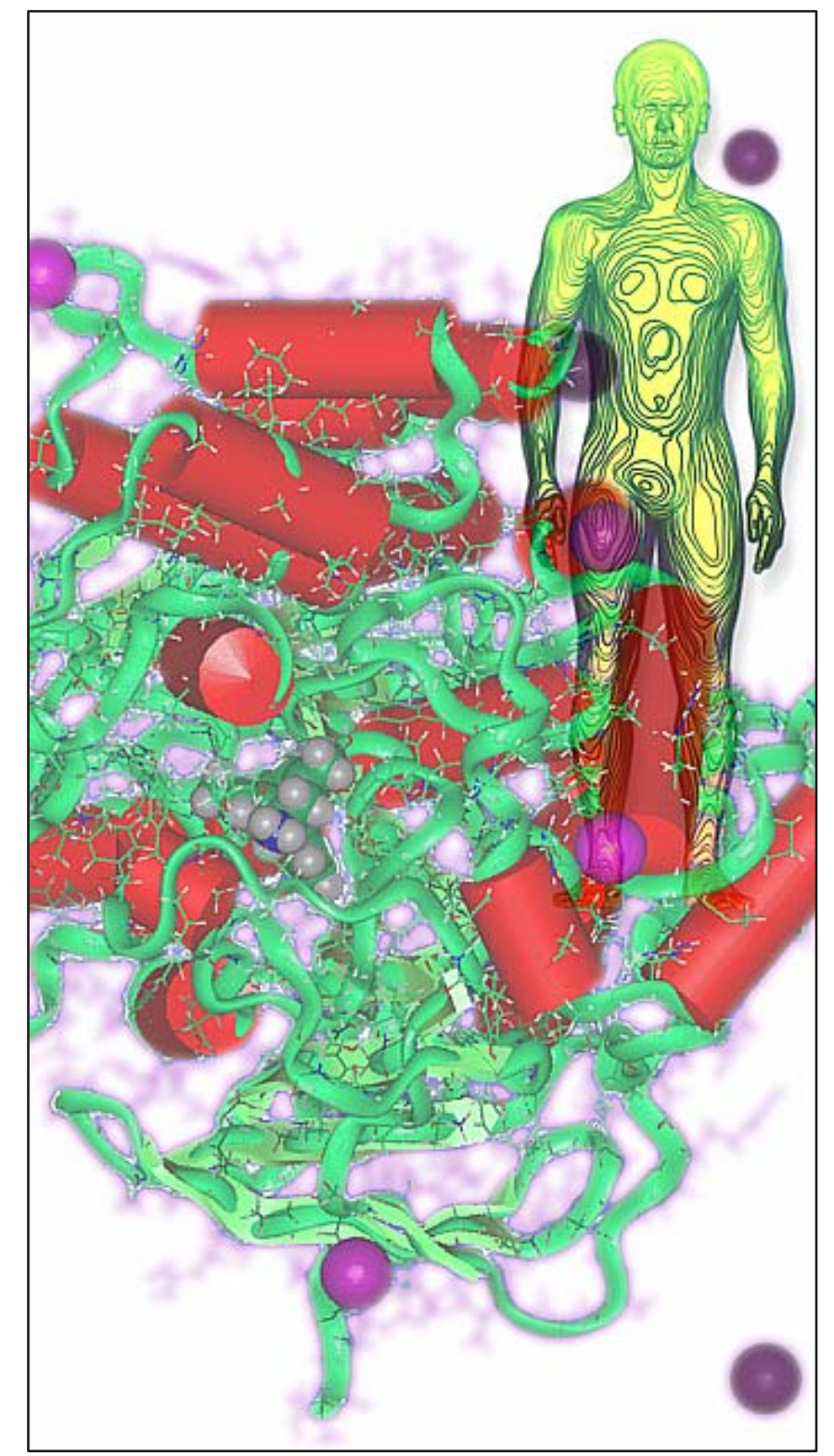

The Genomic Data Explosion

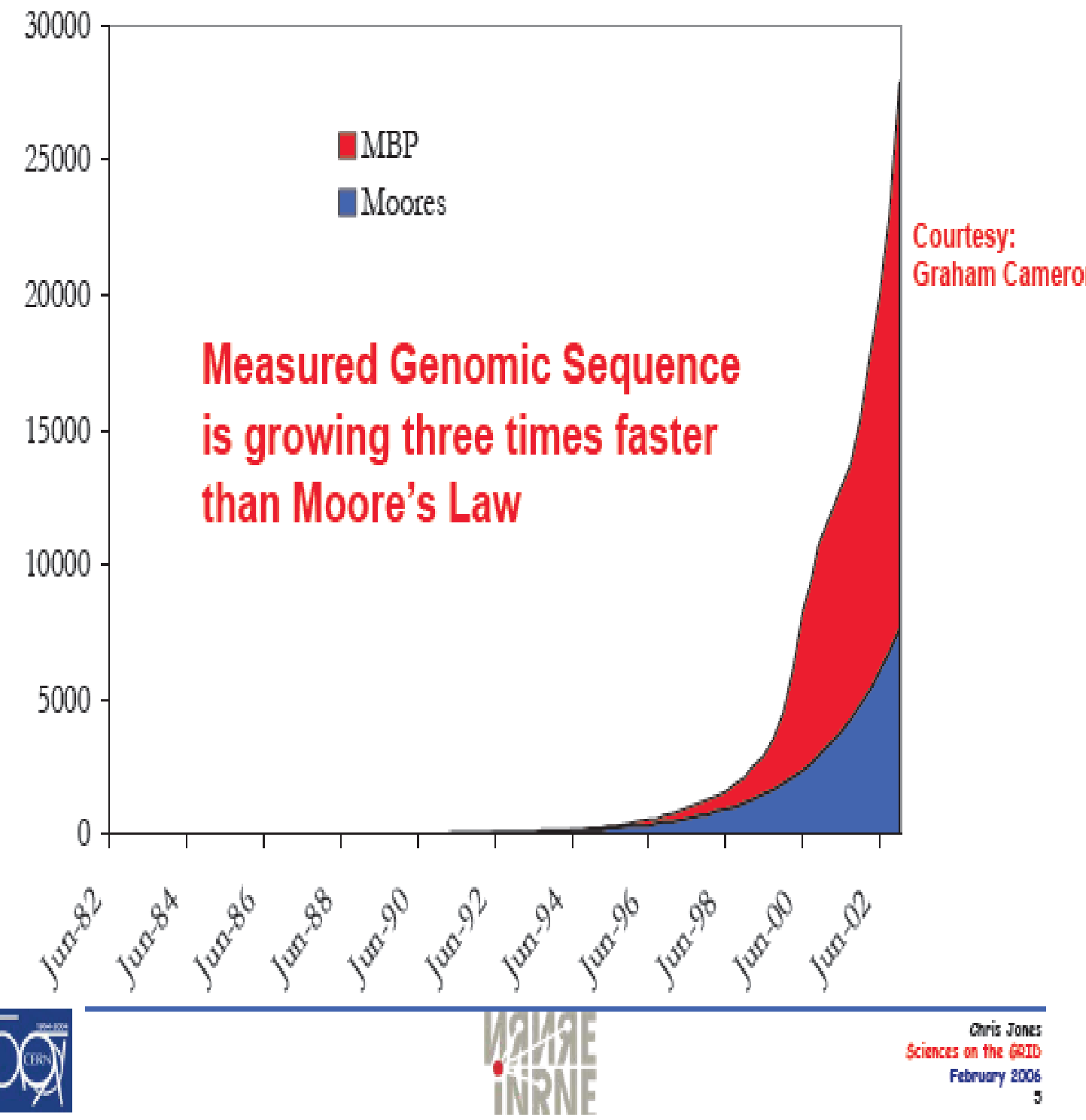

(c) 2006 Hans Hoffmann 


\section{E-Research Support Service for SA}

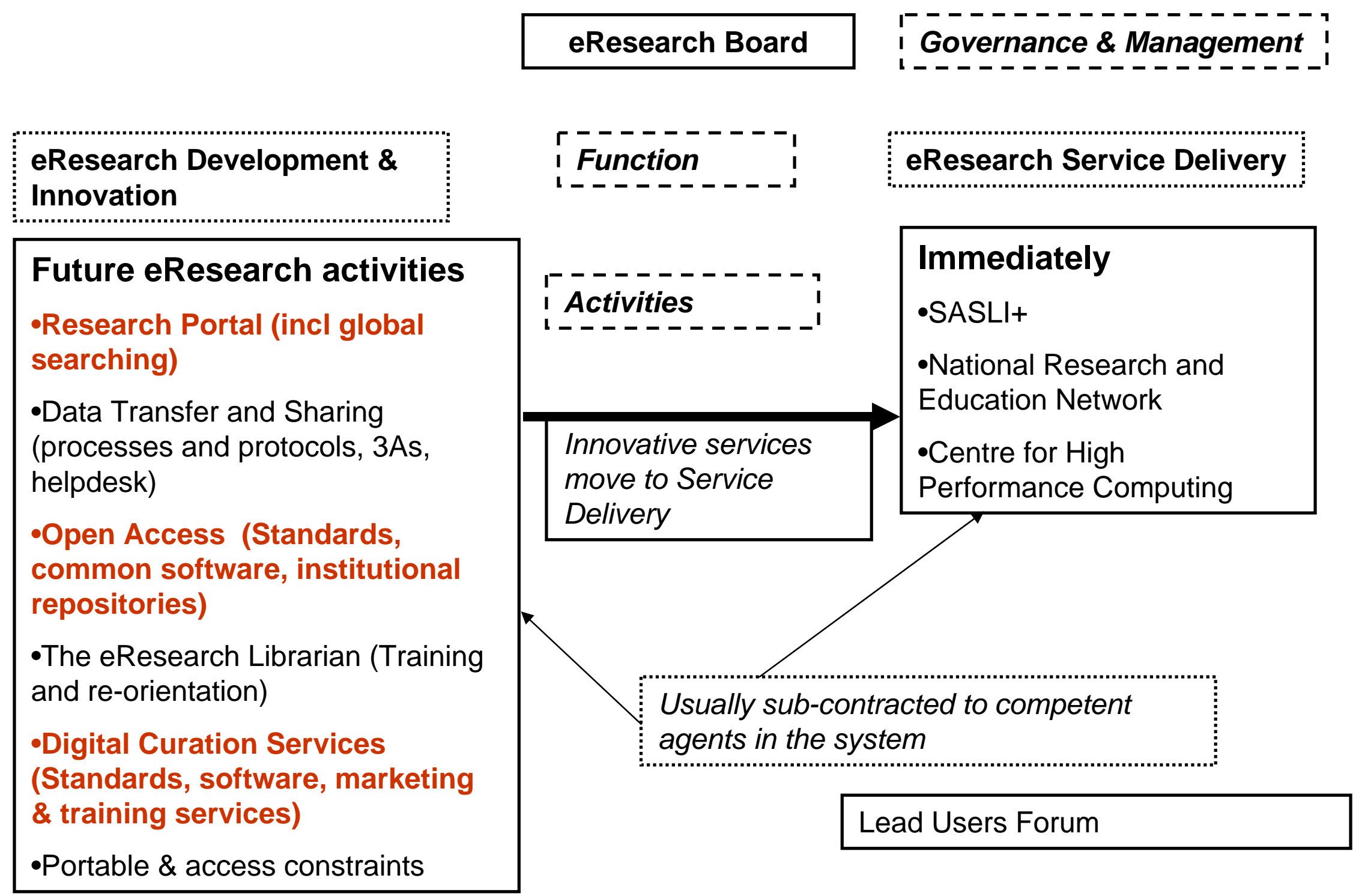




\section{Integrated VRE for Malaria Research in South Africa}

To improve research efficiency

To create a conceptual model of the entire research process in South African context

To surface the VRE needs/constraints across CSIR/UP boundaries - linked to a specific project

To identify the conceptual requirements for developing a pilot VRE for the CSIR/UP project

Virtual

Research

Environment

Researchers: Drs Heila Pienaar (UP) \& Martie van Deventer (CSIR)

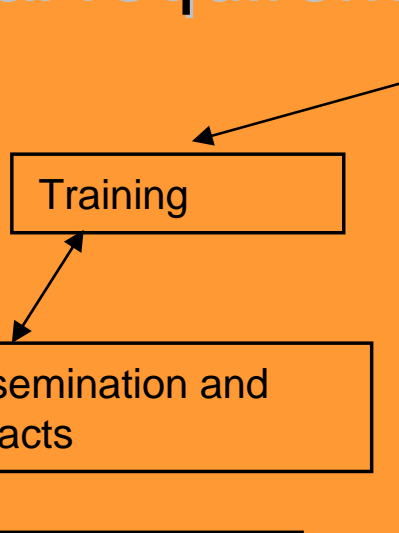
(daily activities relating to research agenda)

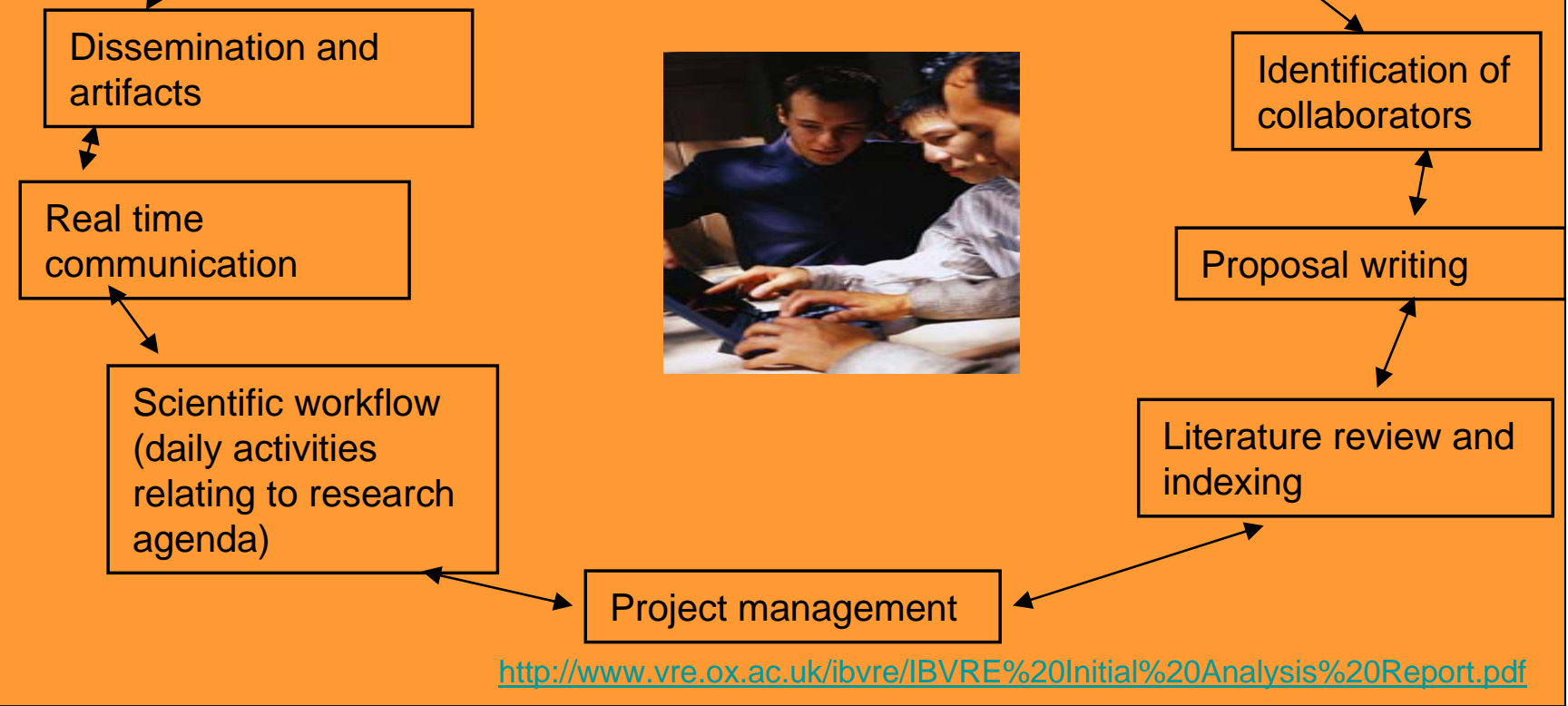

Scientific workflow

\section{Identification of research area in wider context}
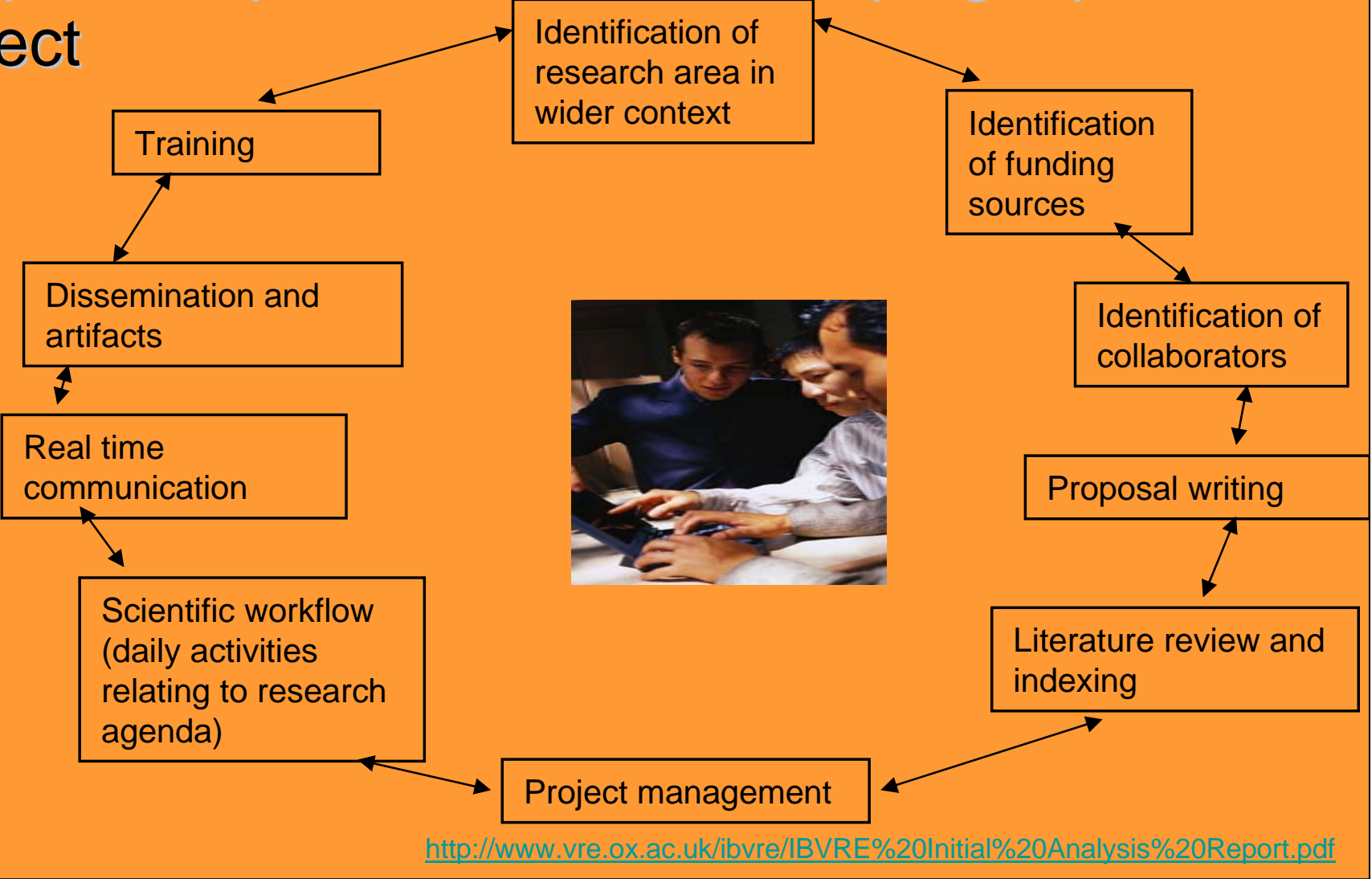

Identification of funding sources 


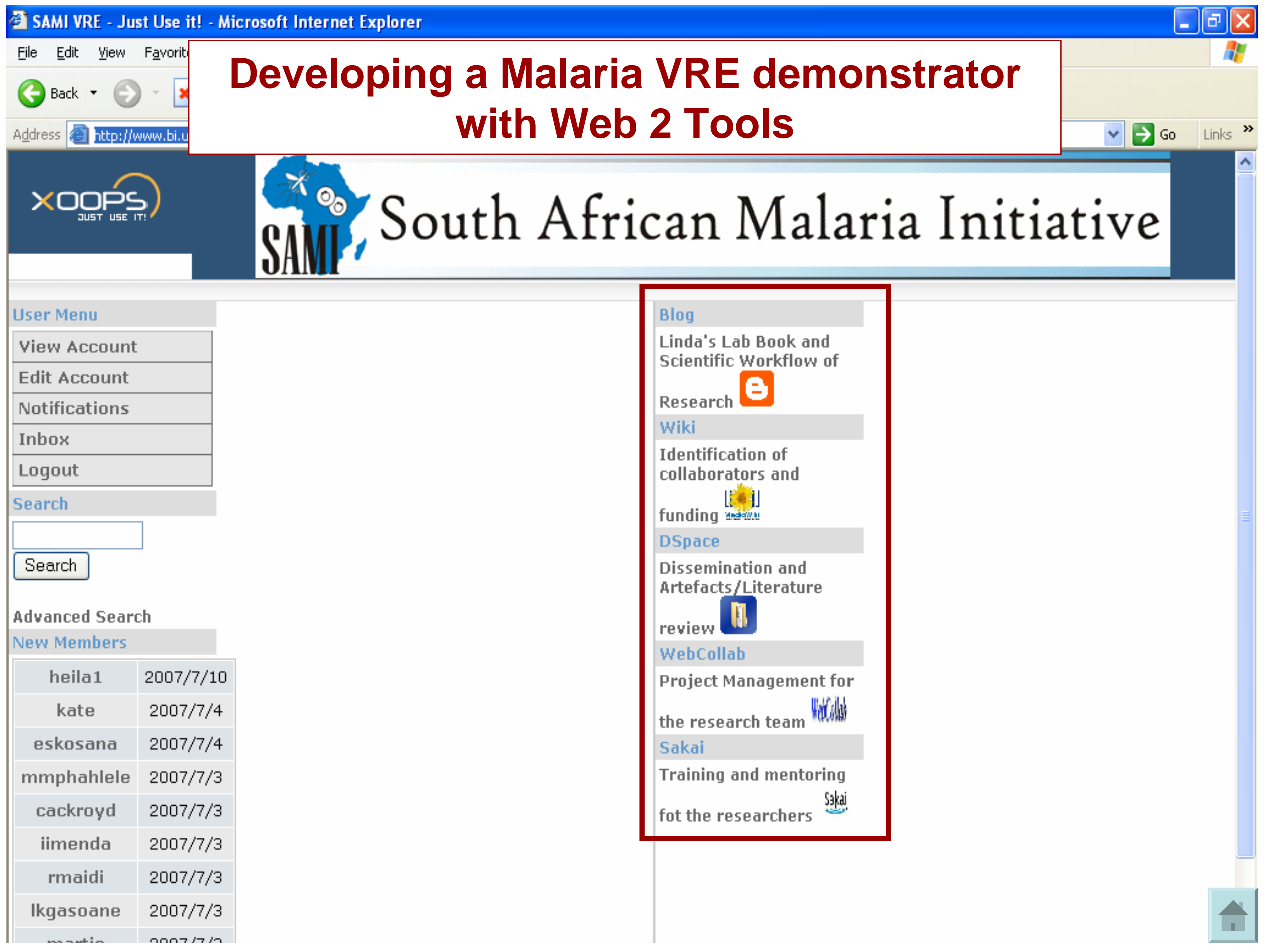




\section{Creation of emerging technology committee}

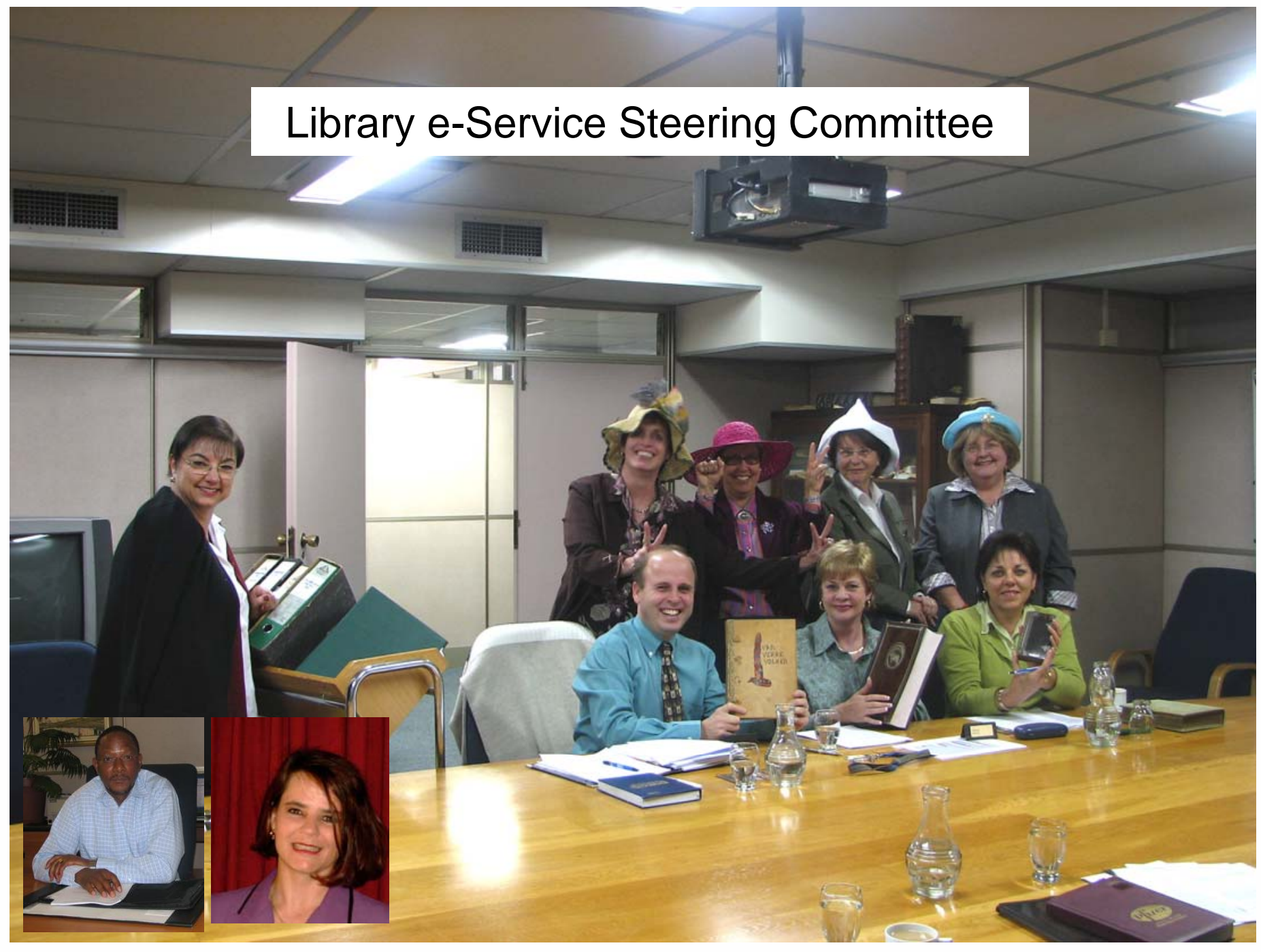




\section{Library e-Service Steering committee: terms of reference}

1. Purpose: The main purpose of this strategic steering committee is the creation of the Library e-Service and the co-ordination of Library e-Activities in support of UP research, teaching and learning.

2. Composition:

Library executive management team member responsible for Library e-Information strategy is ex officio chair

Library executive management are ex officio members

Chairs of Library e-Steering committees are ex officio members

Leader of Library IT unit is ex officio a member

Faculty library mangers (2 or 3 ) to facilitate innovation transfer

3. Terms of reference:

To co-ordinate the implementation of the Library e-Information strategy

To co-ordinate Library e-Services, e-Products \& e-Initiatives on a strategic level

To create \& align Library e-Steering committees e.g. Library Web steering committee, Library System steering committee

To co-ordinate the different e-Budget requests \& spending e.g. IT budget, IT systems budget, Library strategic plan

To align Library IT policies \& architecture with UP IT policies \& architecture

To create \& maintain the necessary personal networks with UP, national, regional \& international stakeholders, opinion leaders \& experts

To be aware of \& to implement new relevant IT trends \& e-Applications

To communicate \& market new e-Trends \& e-Applications 


\section{Integration with e-Learning environment}

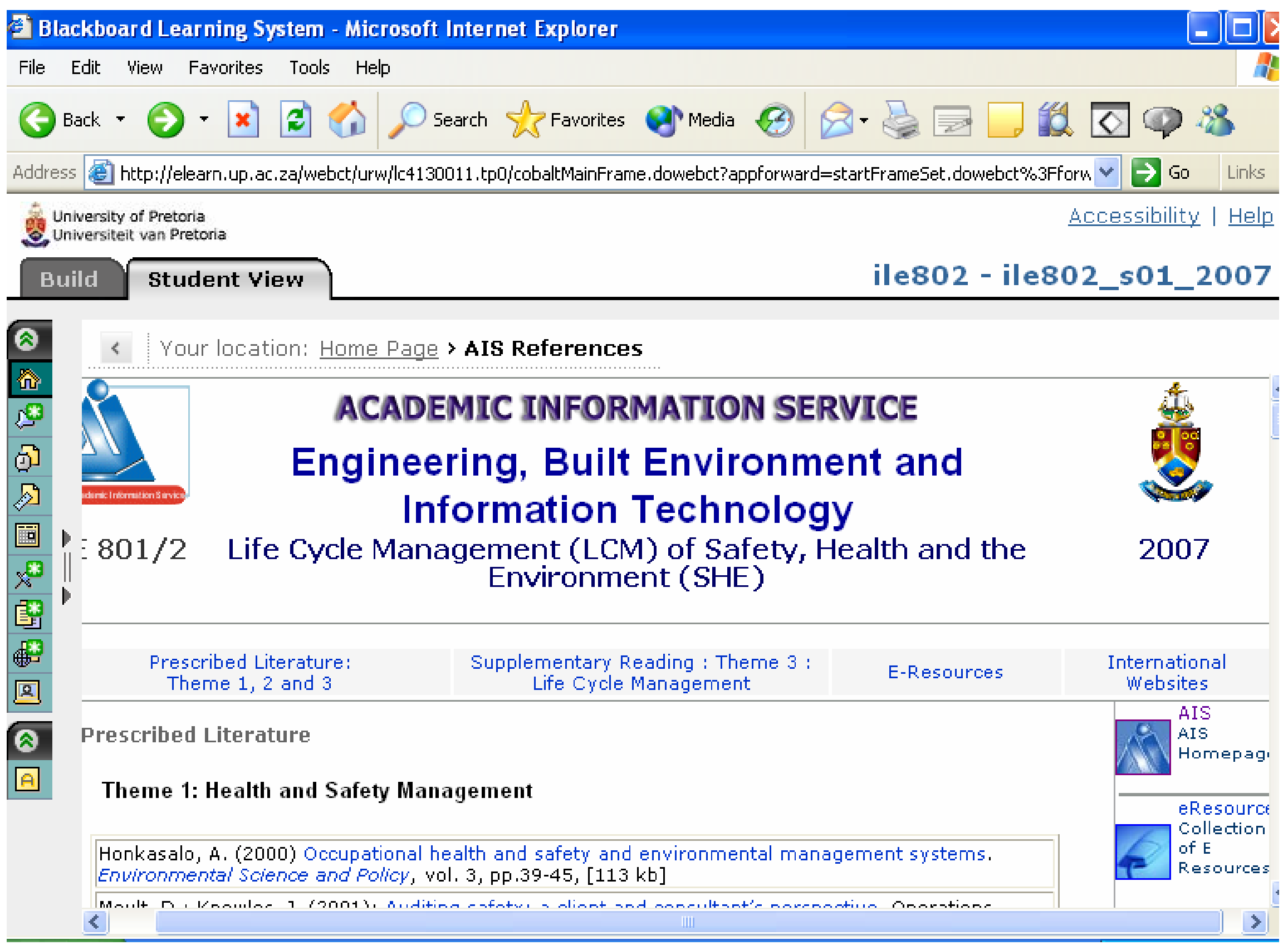




\section{Federated search}

\section{Google Scholar + Scholar SFX = Solution for Africa}

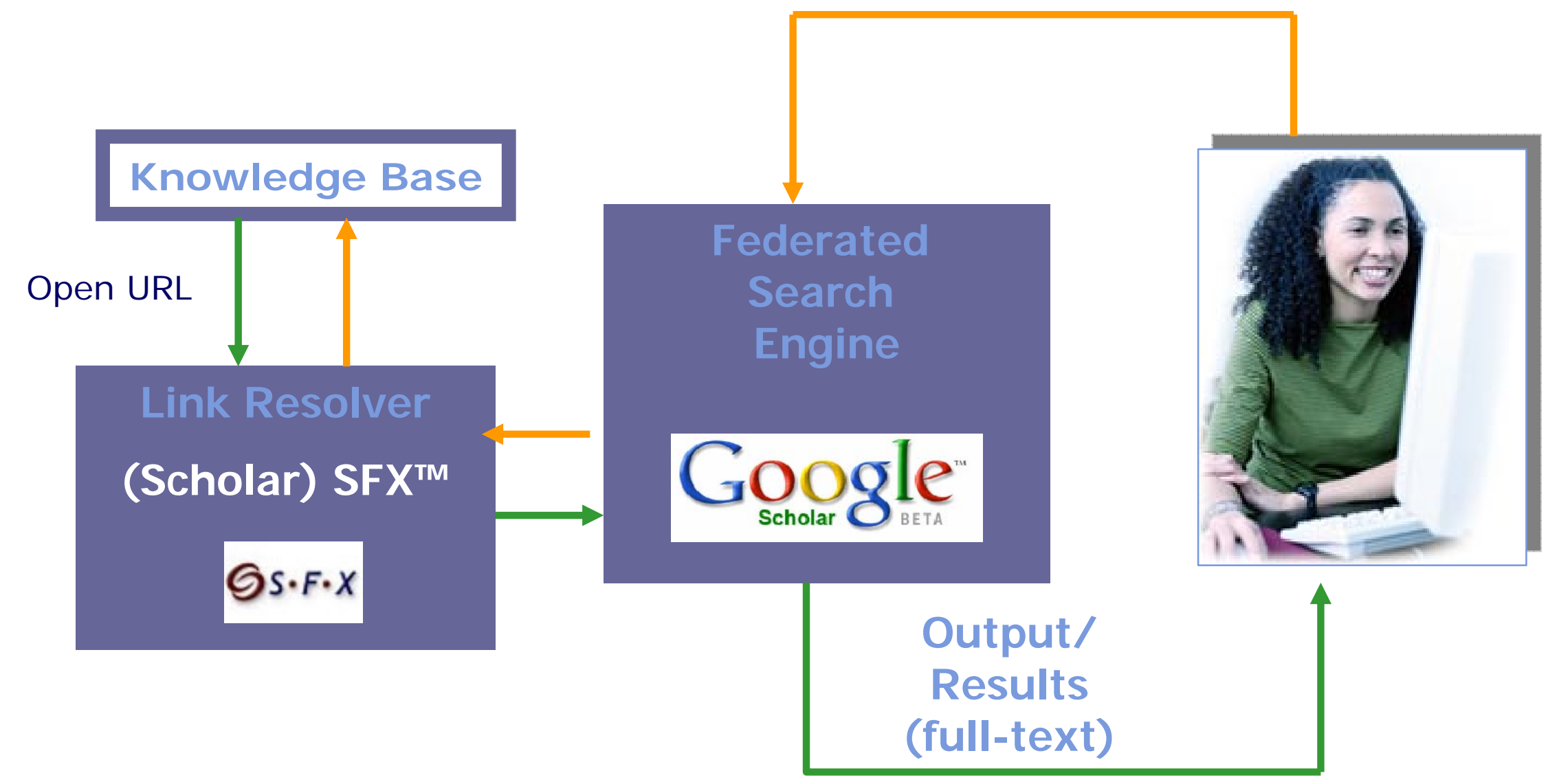


Address [3ttp:i/0-scholar.google.com.innopac.up.ac.zalscholar?q=knowledge+management+libraries\&hl=en\&dr=8btnG=Seal $\vee$

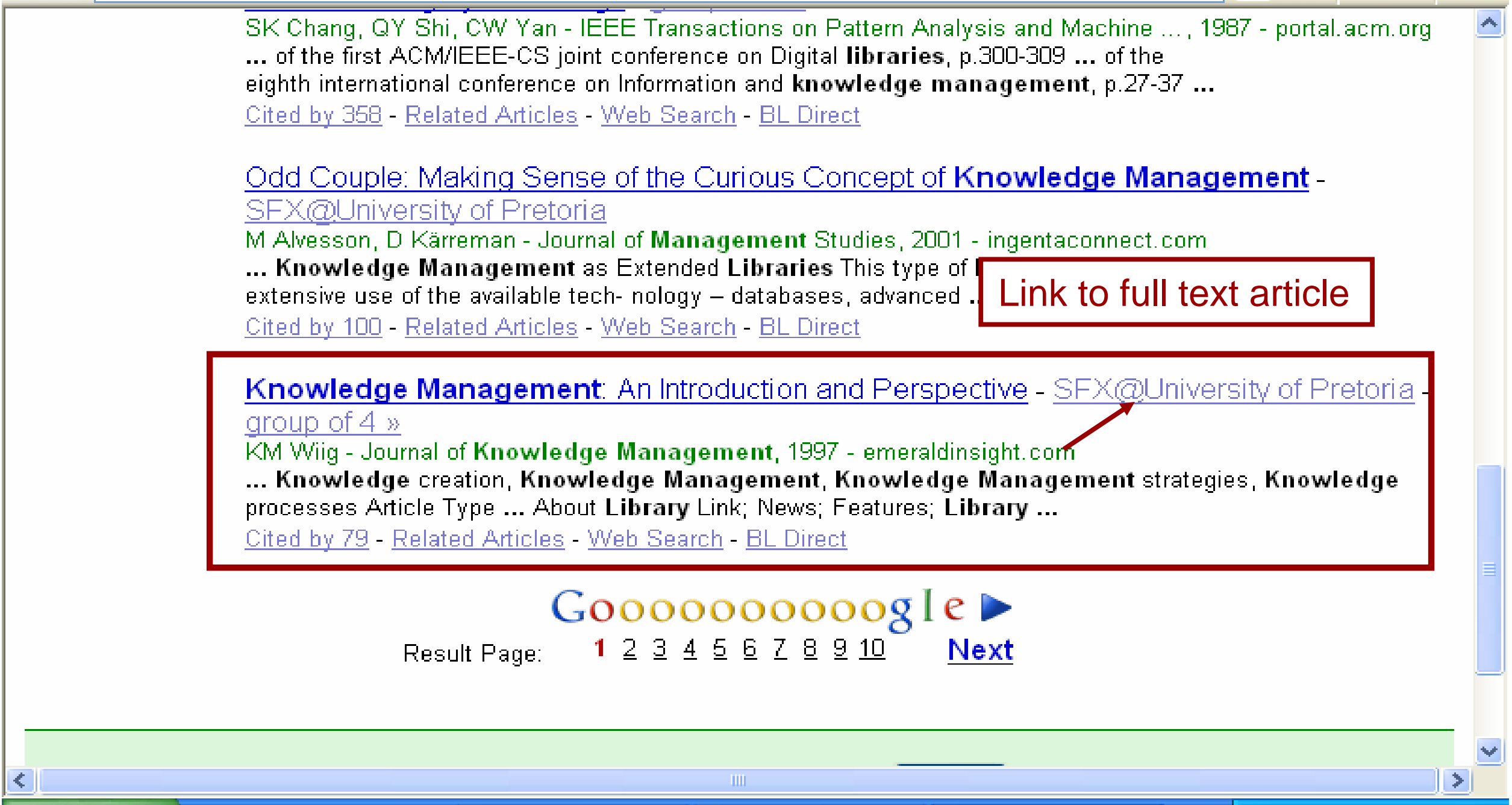


File Édit View Favorites Iools Help

目

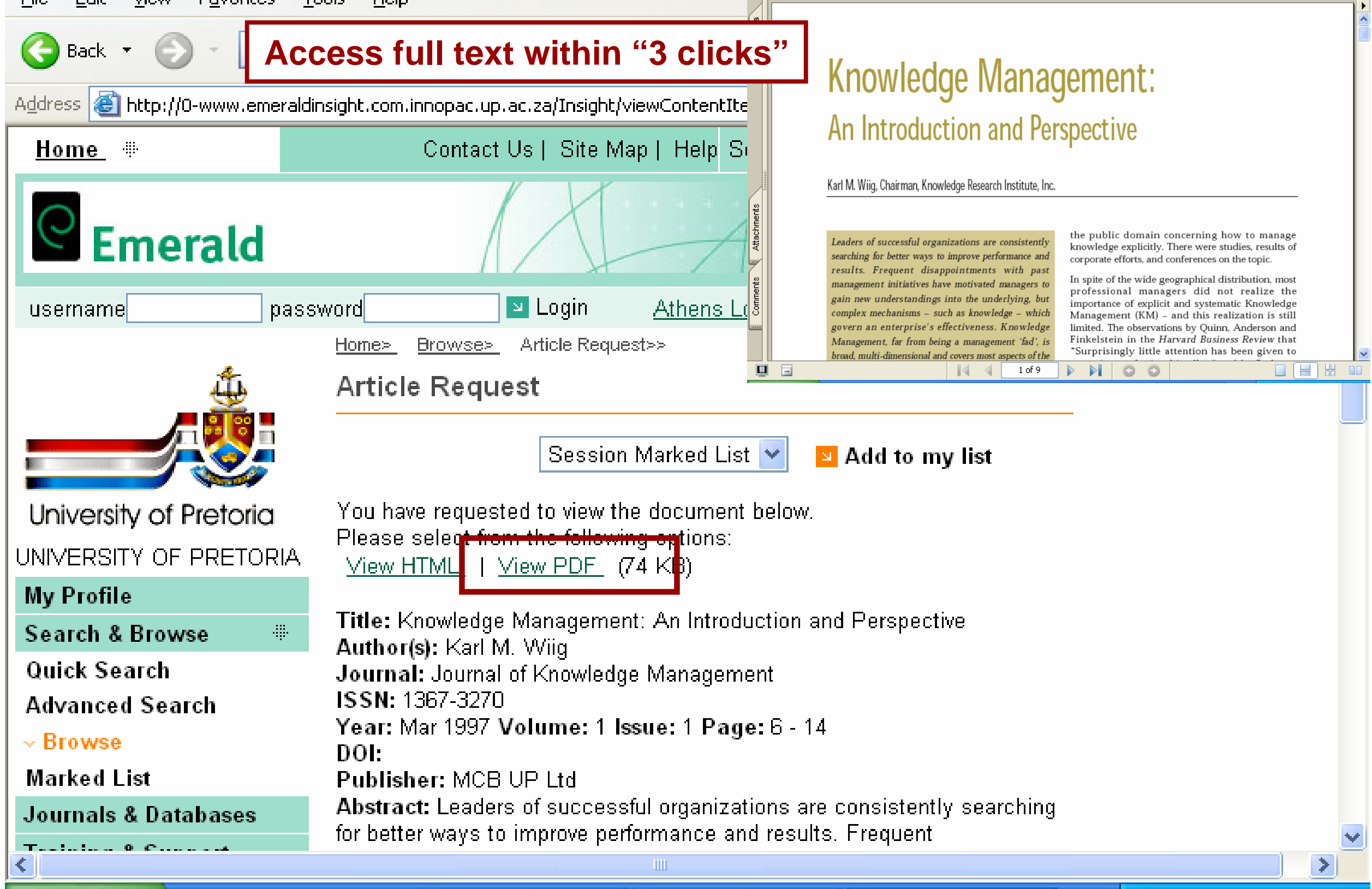




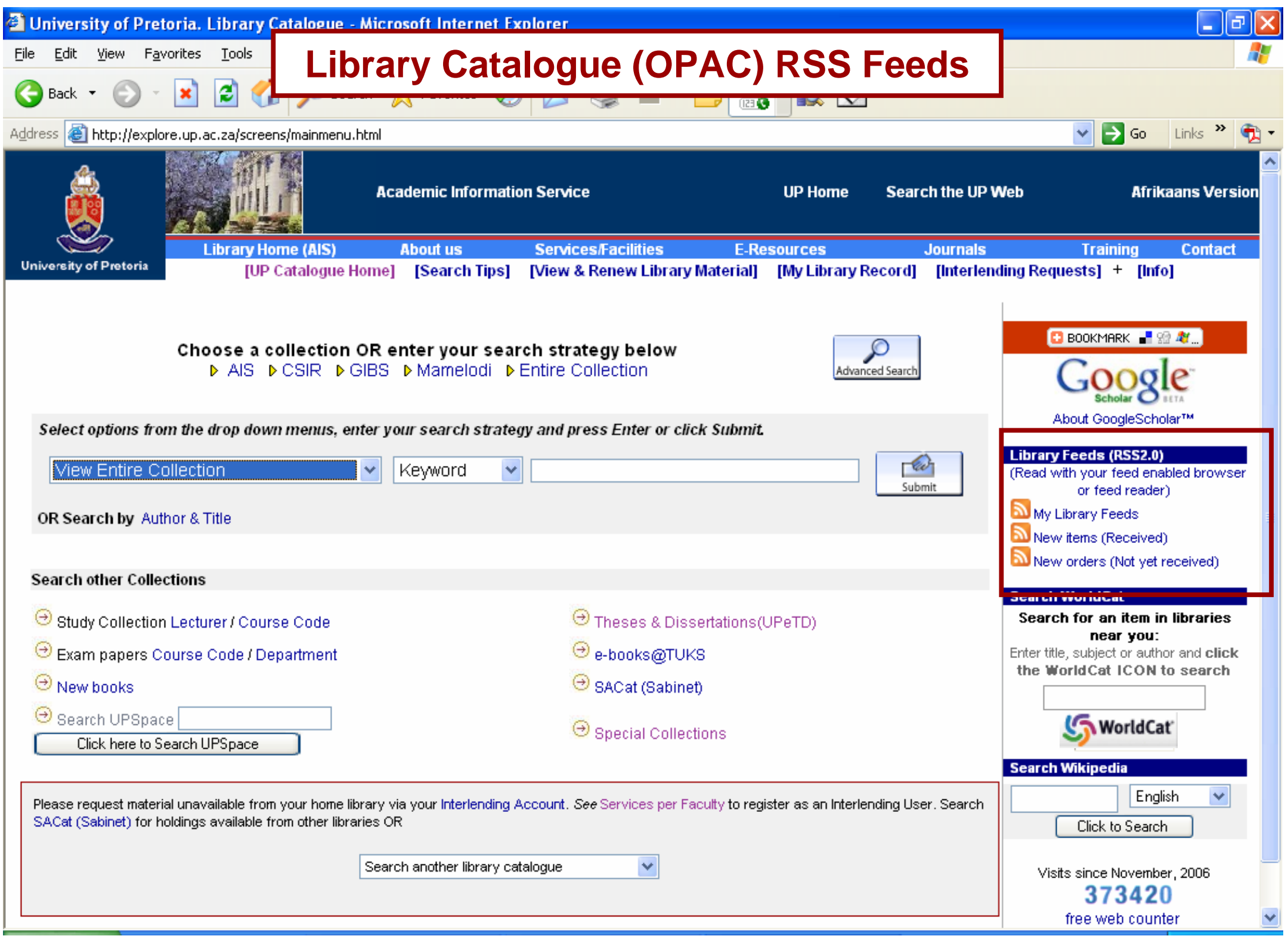


S' University of Pretoria/CSIR /All Locations - Microsoft Internet Exolore

Eile Édit view Favorites Iools $\underline{H}$ e

Back - 9

x 20

Library Catalogue - Book Cover

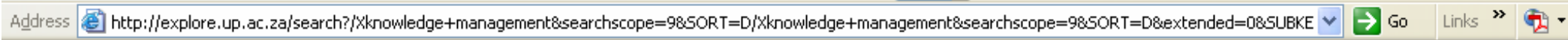
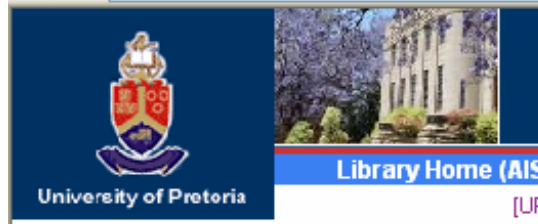

Academic Information Service

UP Home

Search the UP Web

Afrikaans Version

ServicesfFacilities

E-Resources

Journals

Training Contact [UP Catalogue Home] [Search Tips] [View \& Renew Library Material] [My Library Record] $\quad$ [Interlending Requests + Info]

Logged in at University of Pretoria/CSIR/Ali LOCations as SMITH, C CMRS

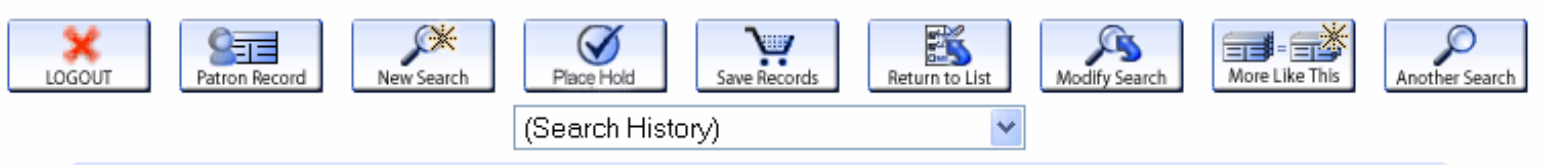

KEYWORD $\checkmark \checkmark$ knowledge management $\quad$ View Entire Collection $\checkmark$ Search

$$
\begin{gathered}
\hline \text { Save as preferred search } \\
\square \text { circulation History } \\
\square \text { Limit search to available items }
\end{gathered}
$$

638 results found. sorted by relevance I date | title

Result page: $\$$ Previous

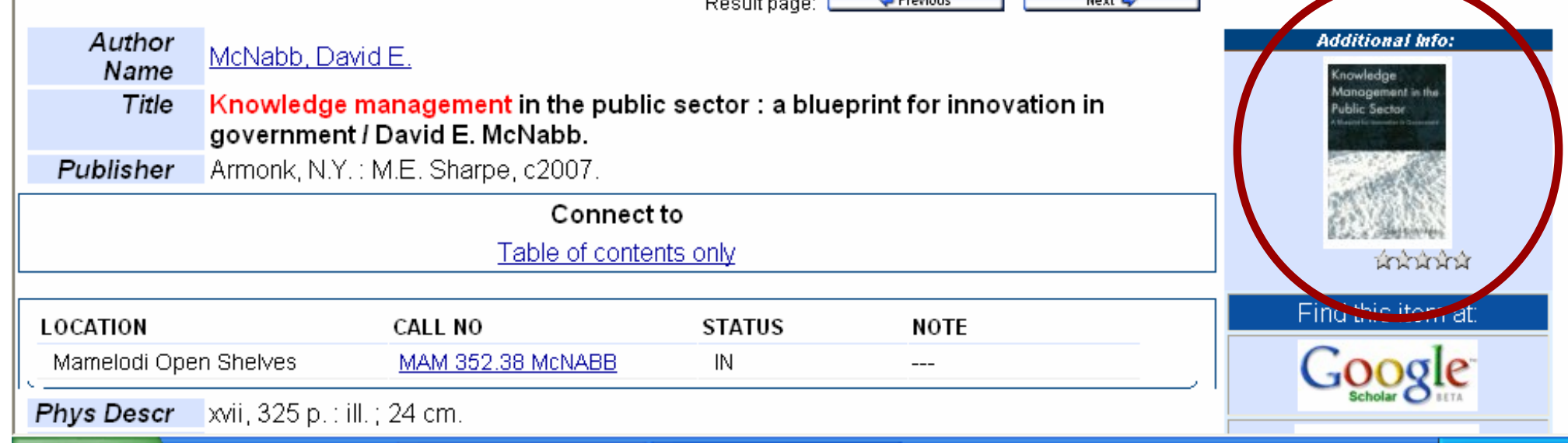




\section{Patron 2.0 =}

\section{from content consumer to content creator}

Current best example is our academics' \& students' involvement with collections on the University's digital research repository, UPSpace.

The Library is responsible for the management of this repository. 


\section{UP Digital Institutional Research Repository}

Specialist / expert roles:

- Metadata: Amelia Breytenbach

- Digitisation: Ria Groenewald

- Open Access: Elsabé O./ Monica H.

- IT Specialist: Leonard Daniels

- Consultant: Theo Bothma

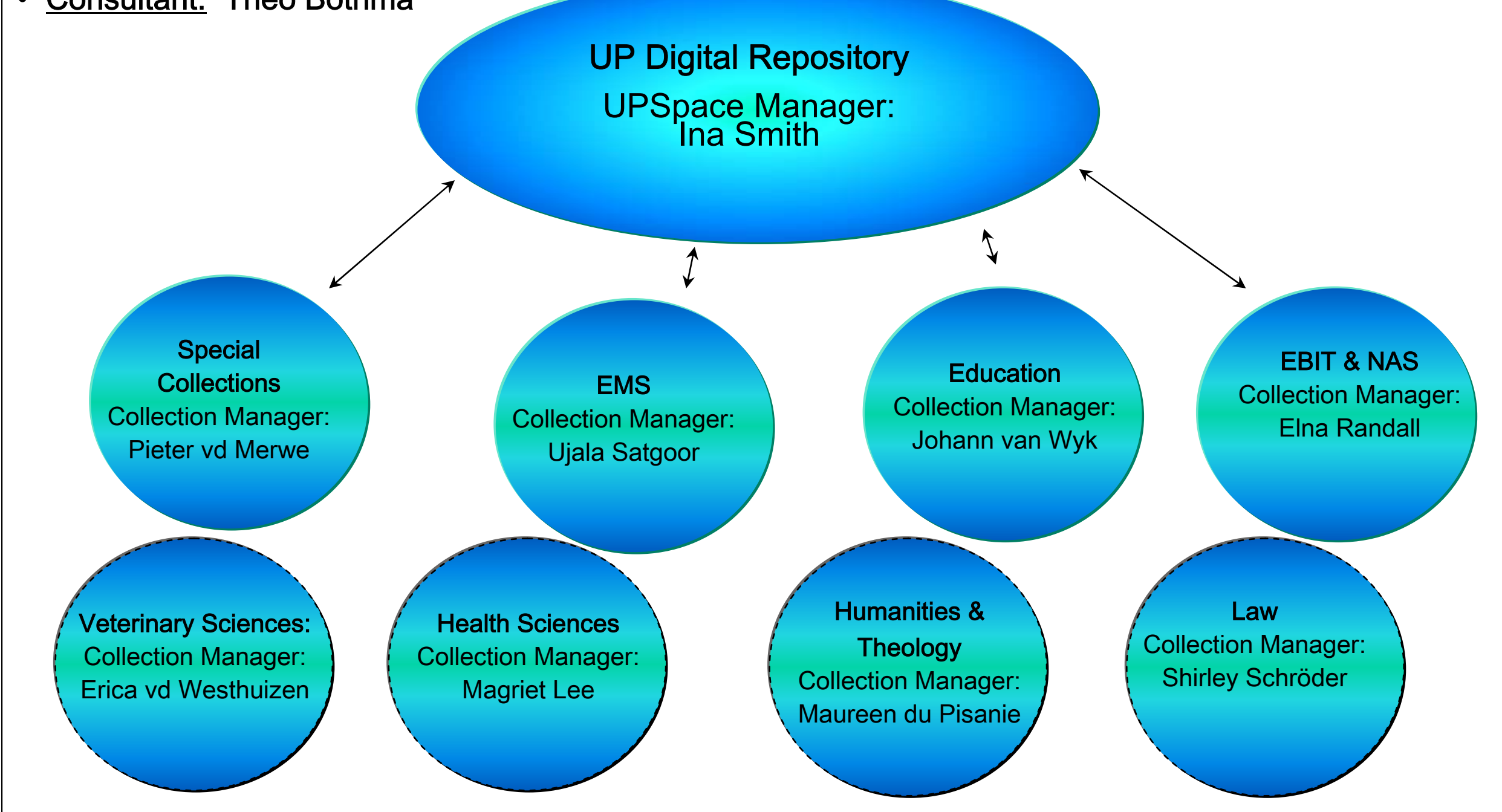




\section{Examples UPSpace Content}
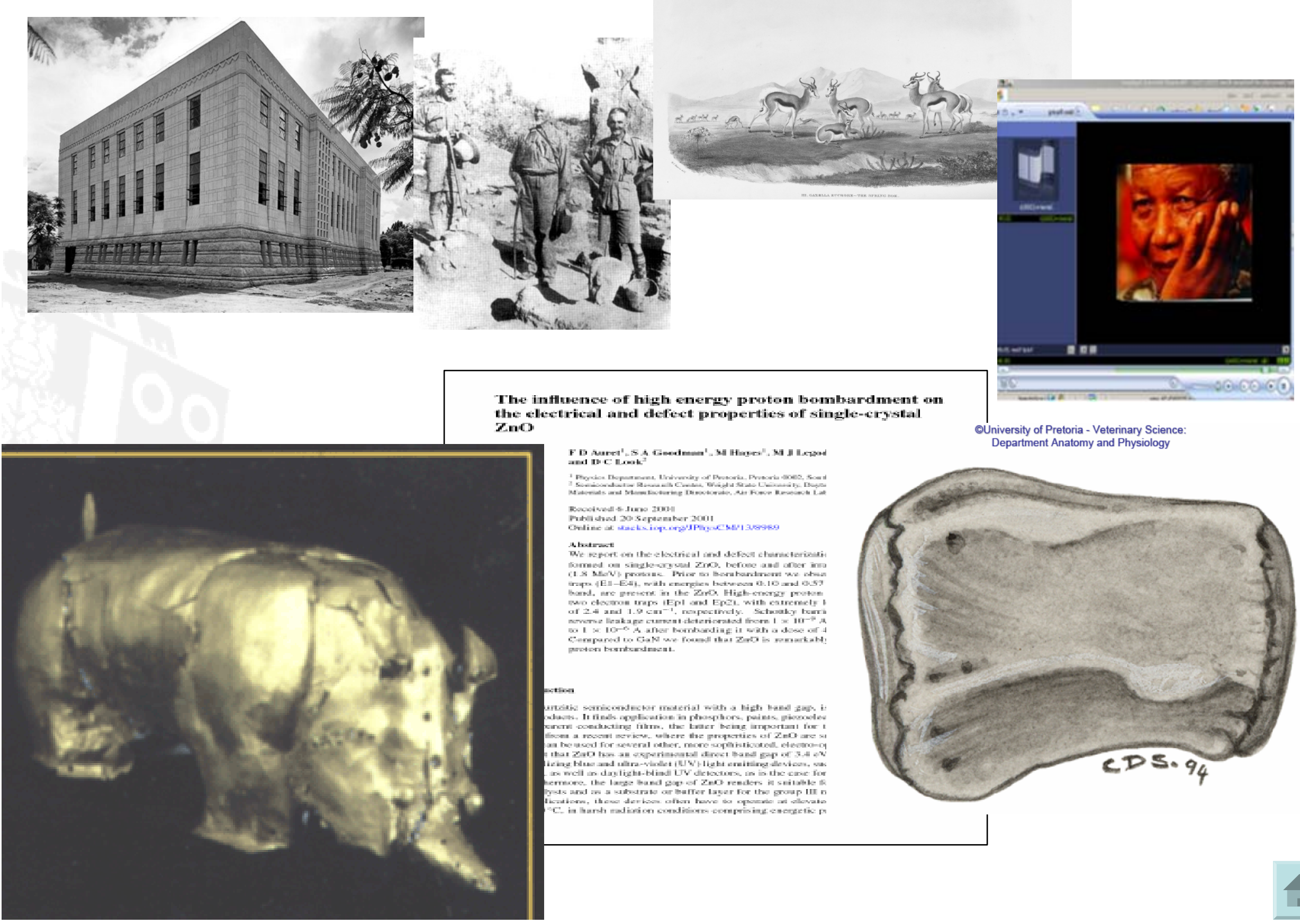

FDimetist

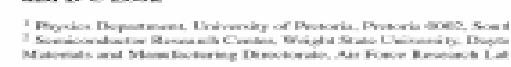

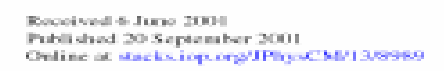

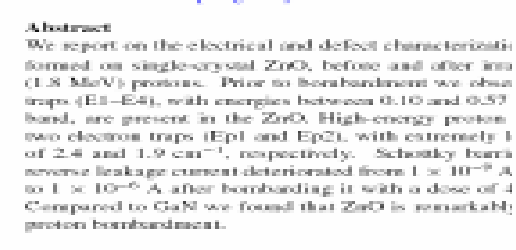
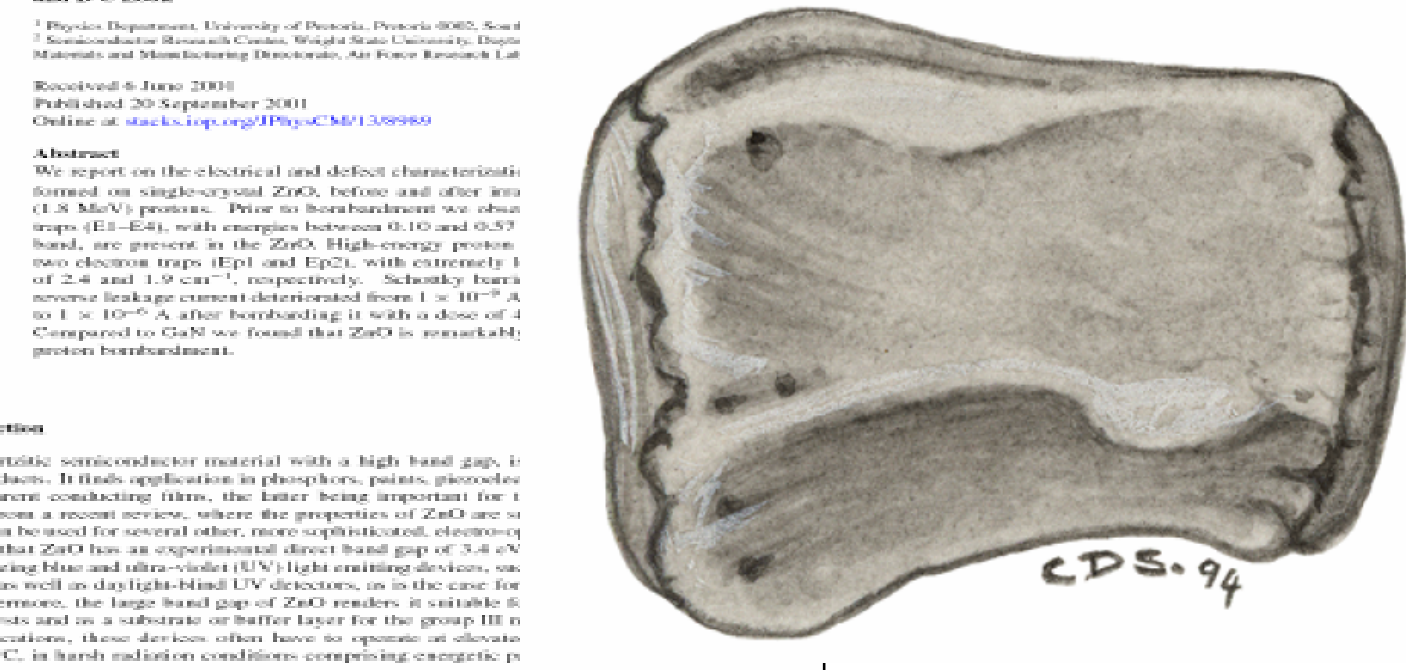


\section{Use of Web 2.0 apps \& services at our Library}

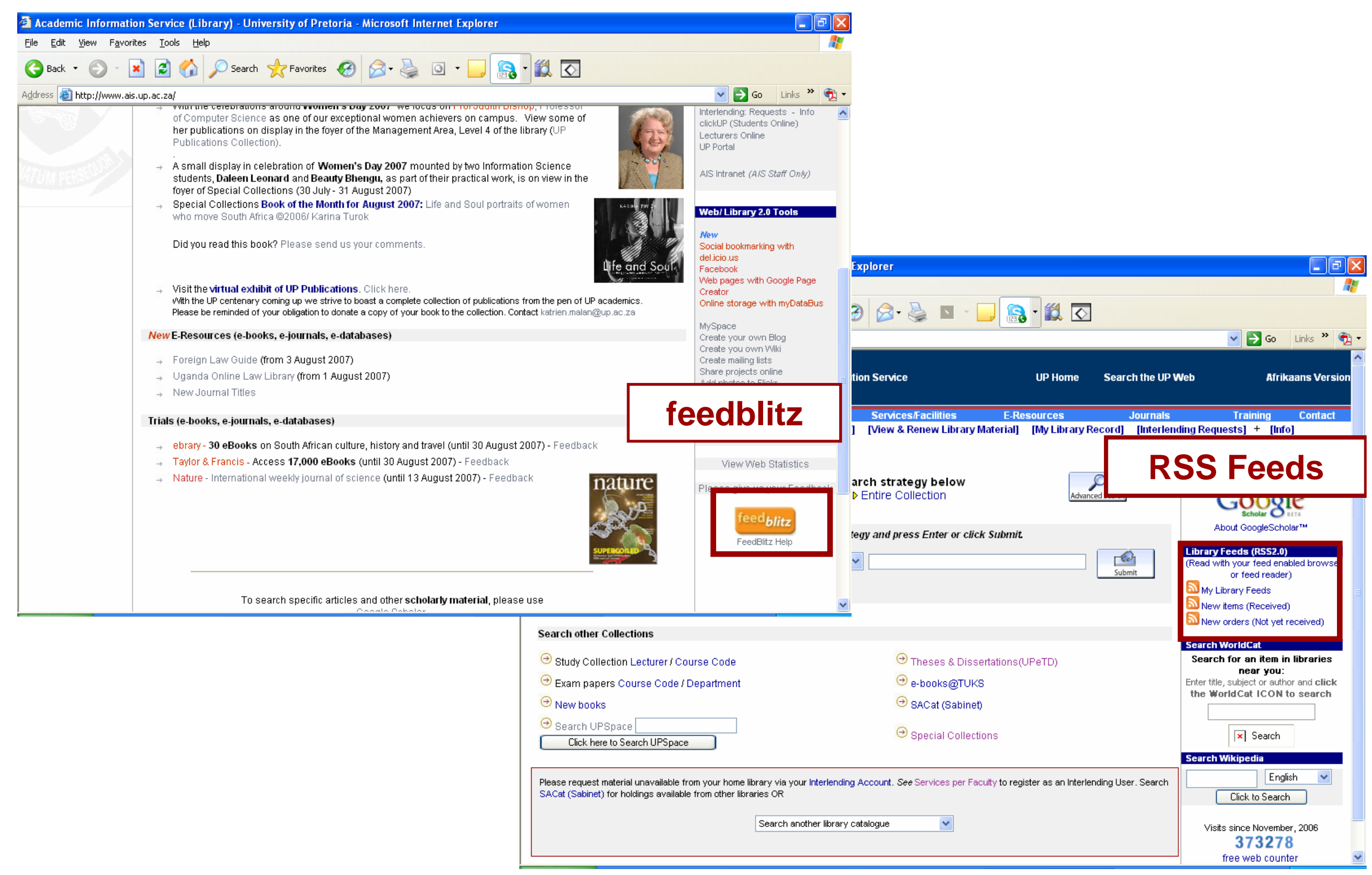




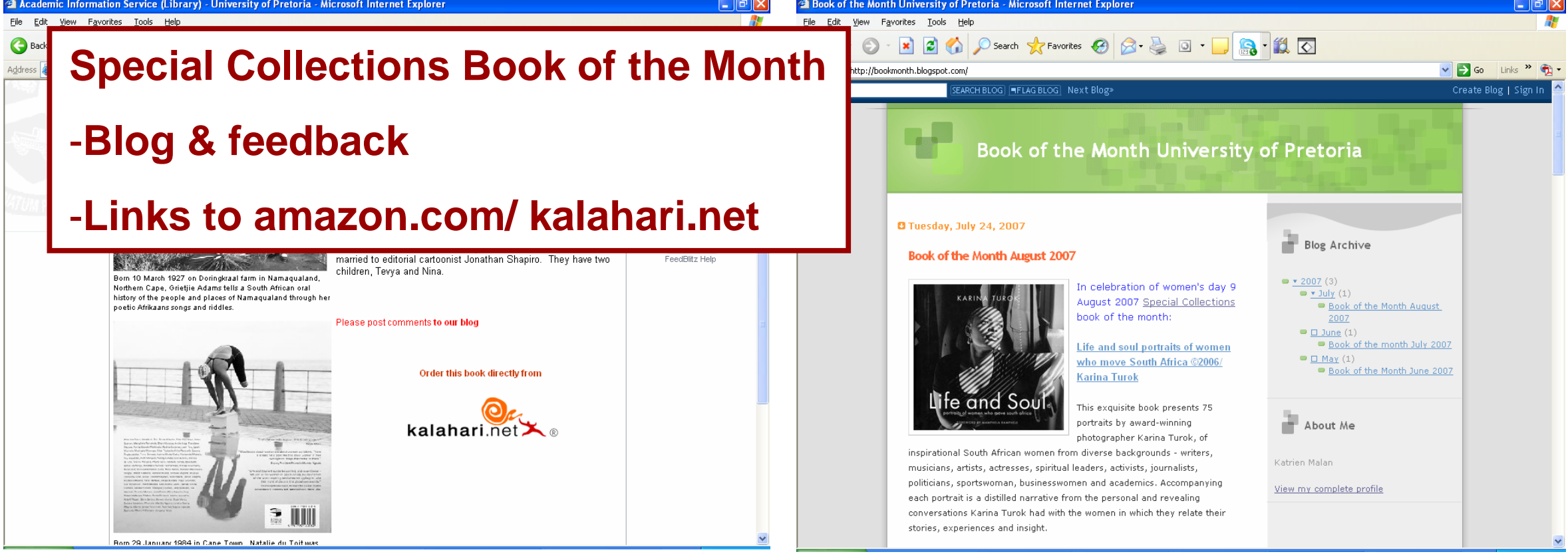
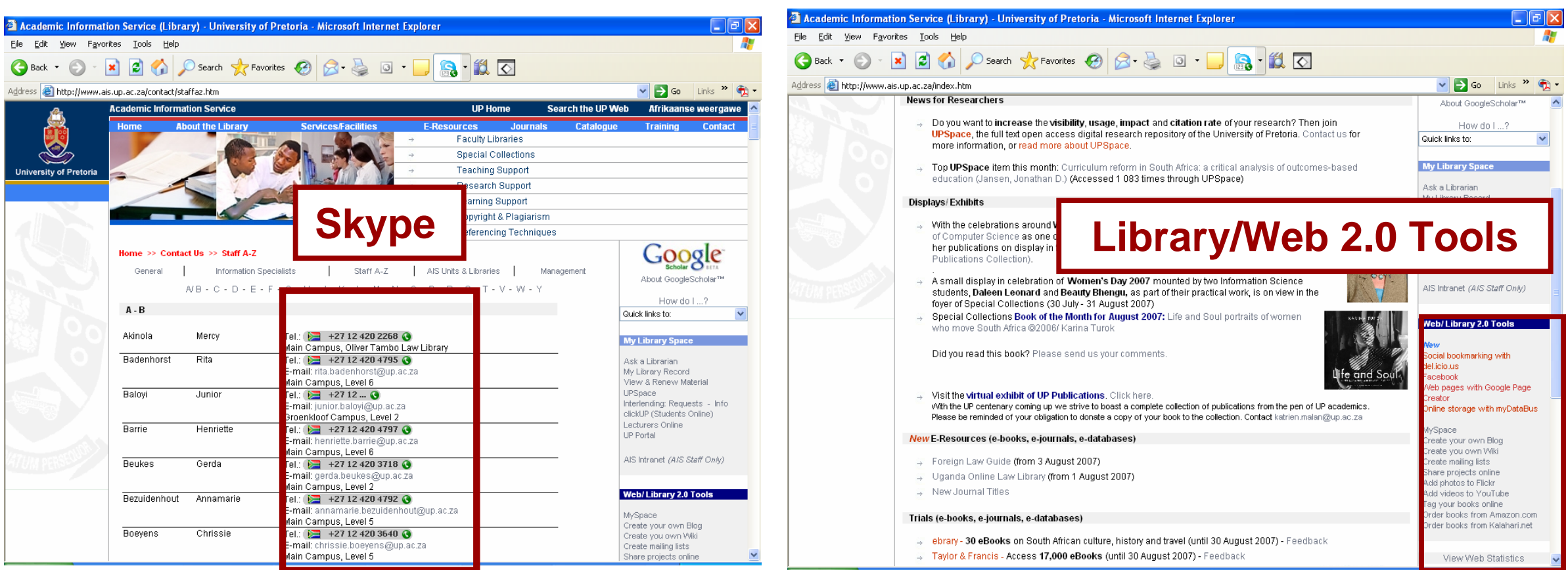


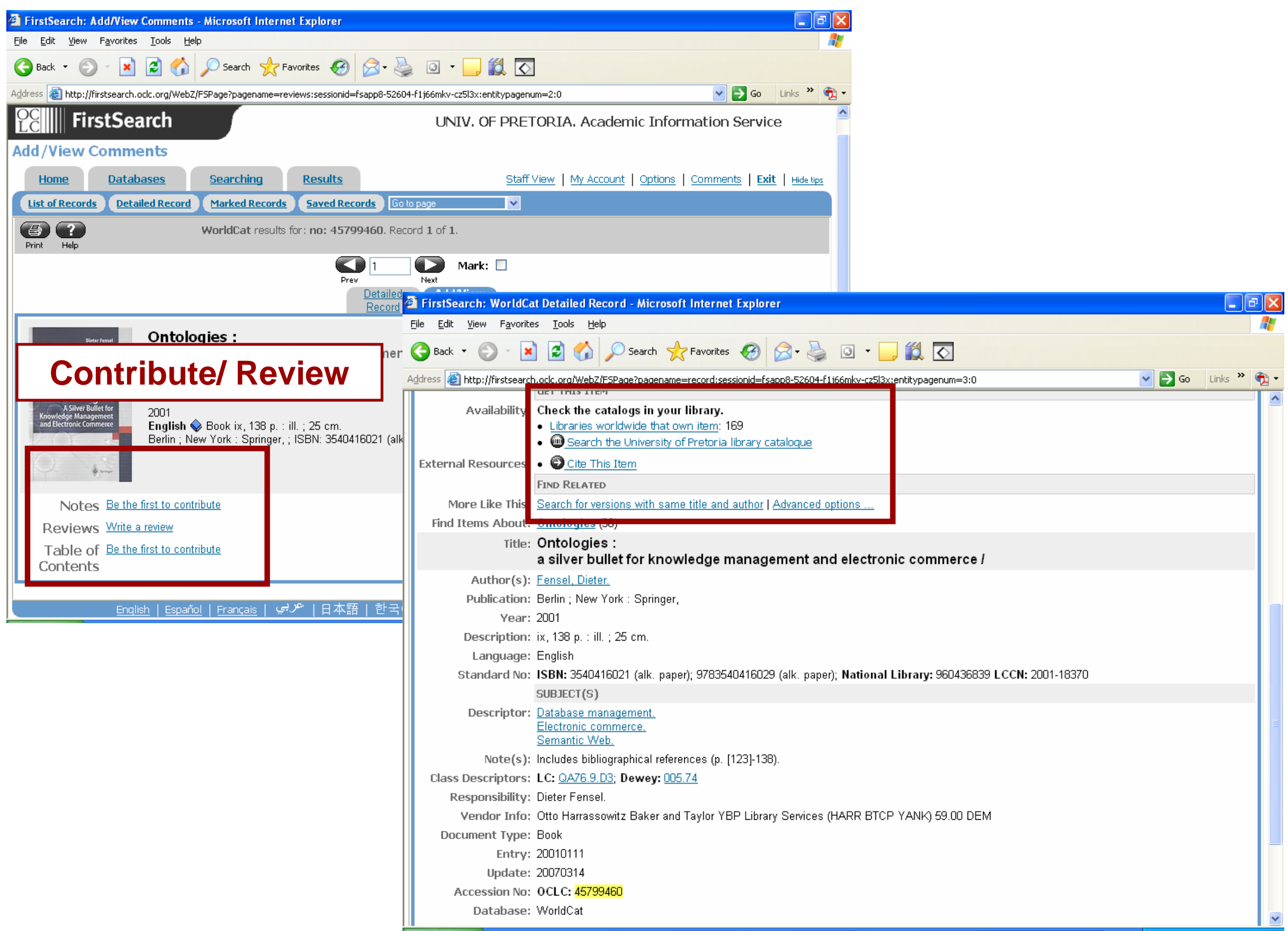



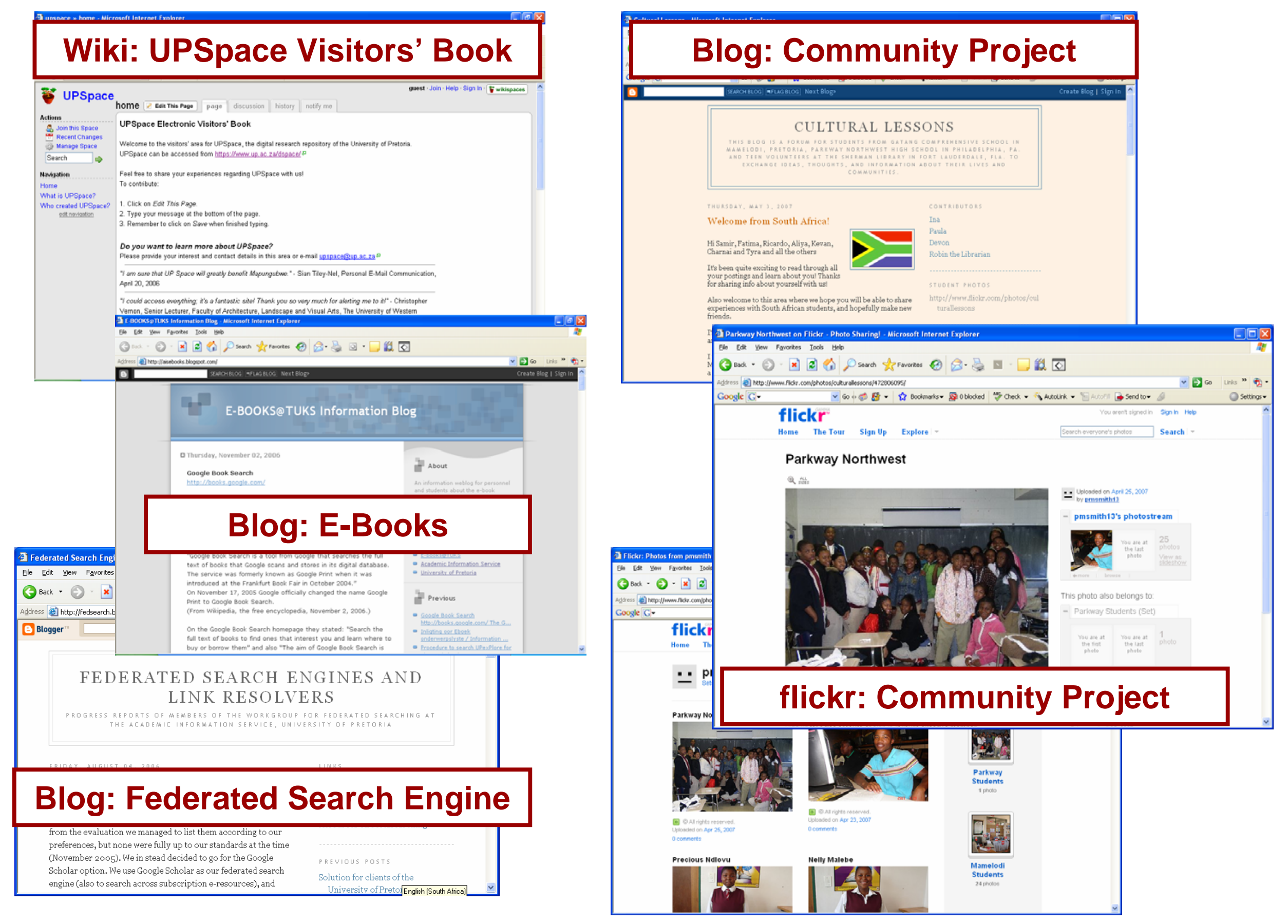


\section{International examples of Web / Library 2 tools}

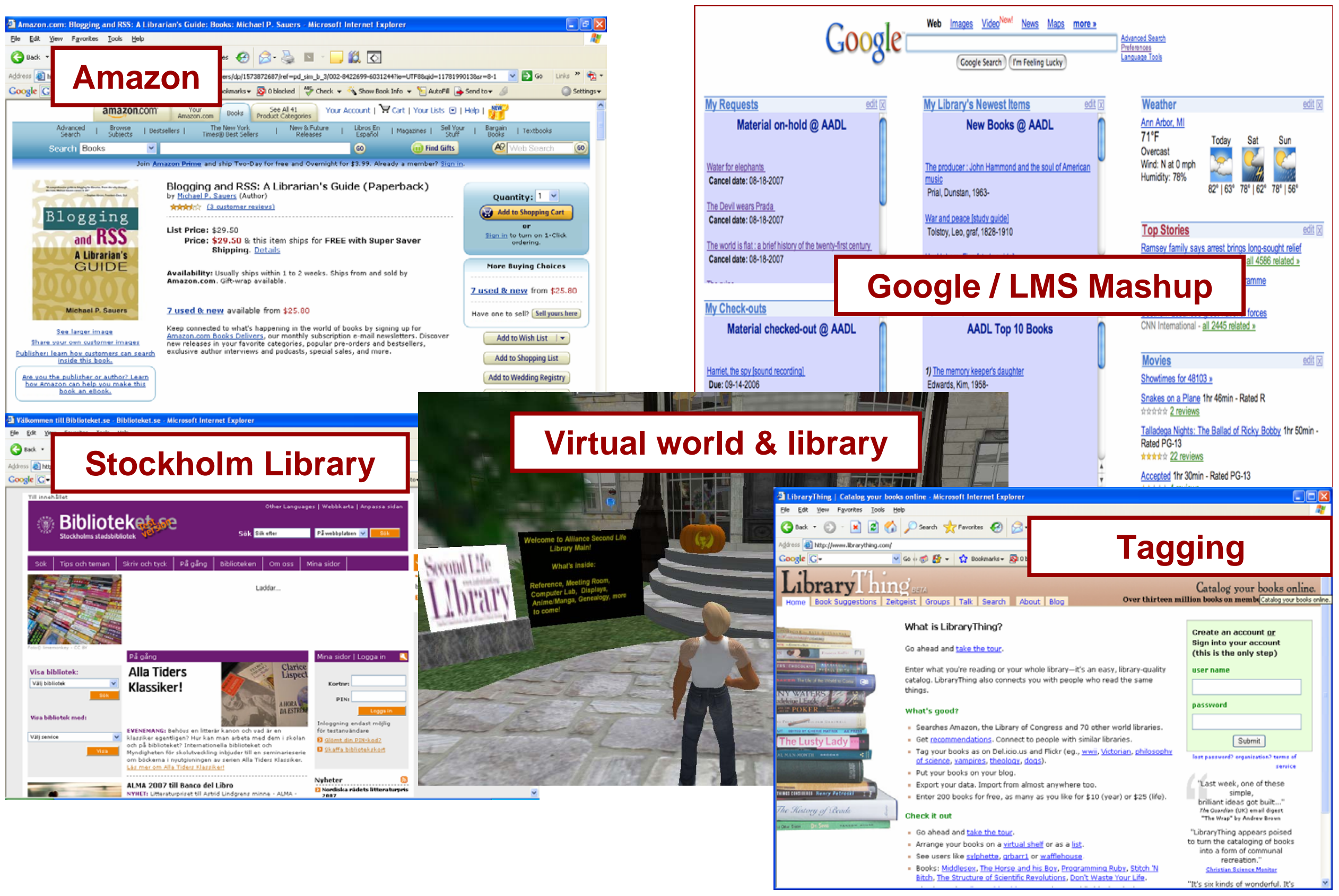




\section{In conclusion ... we are well on our way to become a Library 2.0 Library!}
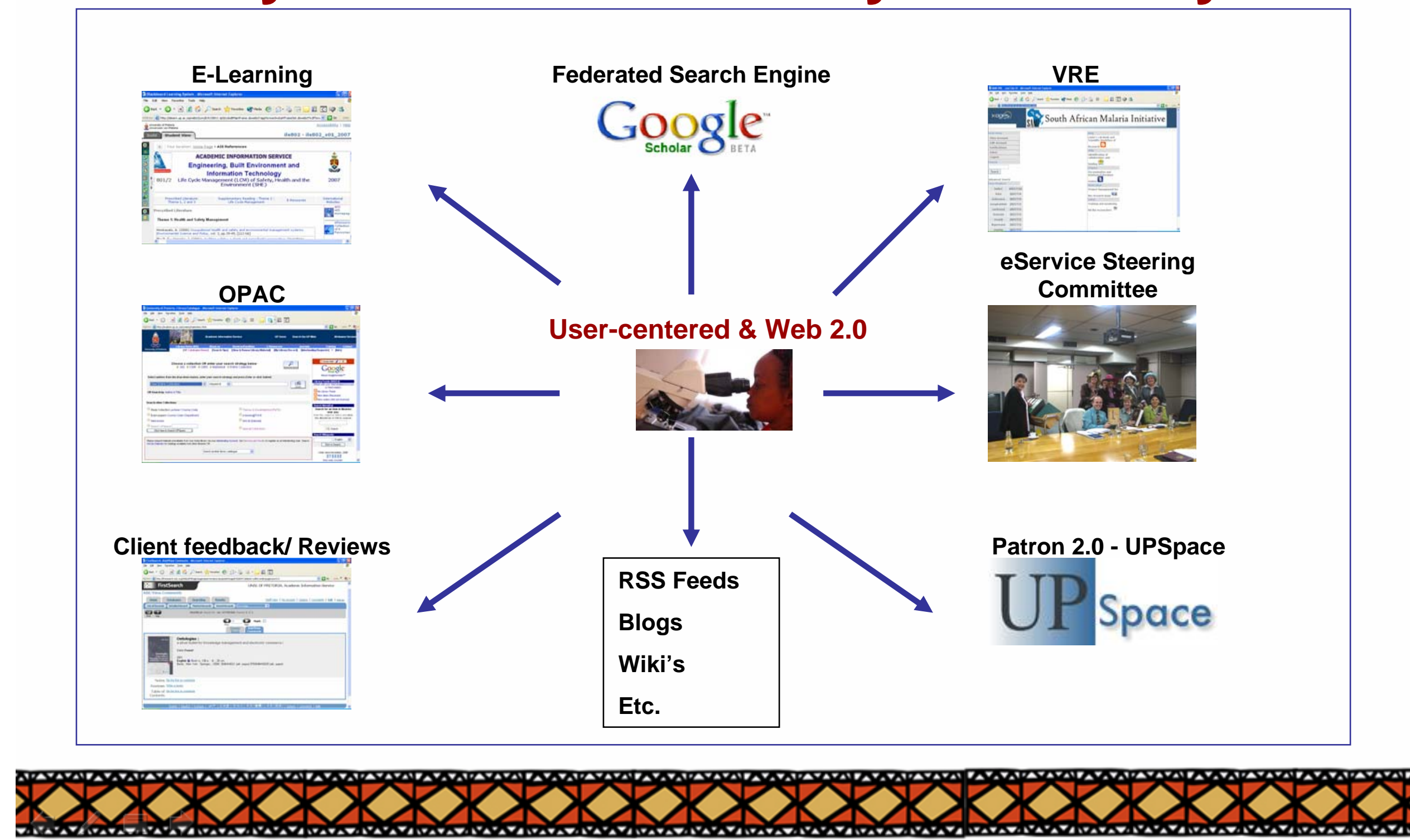


\section{Bibliography}

Hey, T. 2006. e-Science and Scholarly Communication. Academic Libraries: Pro-active partners in learning and research, Stellenbosch, 2-3 November 2006. http://www.lib.sun.ac.za/Sym2006/Presentations/502,1,e-Science

Hoffman, H.F. 2006. Knowledge Utilities as basis for global Sciences. 2nd International Digital Curation Conference Digital Data Curation in Practice, 21 - 22 November 2006, Hilton Glasgow Hotel, Glasgow. http://www.dcc.ac.uk/events/dcc2006/programme/presentations/h-hoffmann.ppt

Mascard, M., Jirotka, M. \& Sieunarine, C. 2005. Integrative Biology VRE Work Package 2: Initial Analysis Report. http://www.vre.ox.ac.uk/ibvre/IBVRE\%20Initial\%20Analysis\%20Report.pdf

Schneider, K. 2007. Library 2.0 Cookbook. http://freerangelibrarian.com/presentations/slissouthafrica2006preconf.ppt Time's Person of the Year 2006: You. http://www.time.com/time/magazine/article/0,9171,1569514,00.html

Van Wijk, C. 2006. University of Pretoria campus building photos. http://members.fotki.com/LadySmiles/

Wikipedia. http://en.wikipedia.org/wiki/Library 2.0 


\title{
Presenters
}

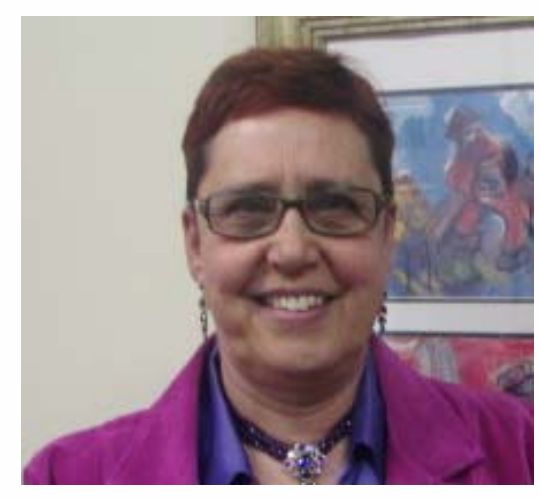

\author{
Dr Heila Pienaar
}

heila.pienaar@up.ac.za

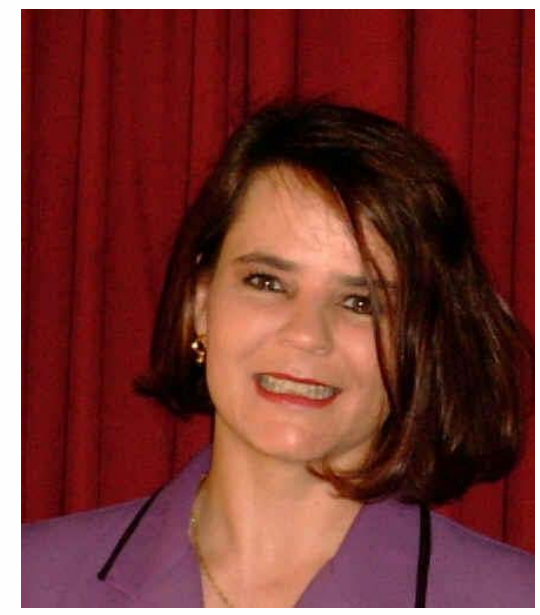

Ms Ina Smith

ina.smith@up.ac.za 